\title{
Pemahaman Hadis Isbāl Dalam Perspektif Sosiologis
}

\author{
(Understanding of Isbāl Hadiths in a Sociological Perspective)
}

\section{Rozian Karnedi}

Institut Agama Islam Negeri (IAIN) Bengkulu, Indonesia

roziankarnedi@iainbengkulu ac.id

DOI: $10.29240 /$ alquds.v5i1.2187

Submitted: 2020-12-11 | Revised: 2021-03-09 | Accepted: 2021-03-30

\begin{abstract}
This study aims to further analyze the differences among Muslims in understanding the isbāl hadith focused on two questions. First, whether the isbāl prohibition contained in various pure hadiths is religious normativity or sociological reasons for particular interests. Second, how is the best way to understand the isbāl hadith prohibition. The study of this issue uses a sociological approach and thematic correlative methods. The study results found that the hadiths that prohibit isbāl are tasyri'iyyah hadith (legal / normative), but the law is not universal but conditional. It happens because the emergence of the hadiths prohibiting isbāl is inseparable from the sociological factor at that time, which was a form of rejection of the Prophet Muhammad PBUH against the jahiliyyah culture. The correlative study of the hadith found that 'illat prohibiting isbāl is khuyyala' (arrogance). The proper understanding of this hadith is a contextual understanding using the rules of ushul fiqh yadūrul hukmi ma'a al-illah wujūdan wa'adaman (the application of the law is closely related to the presence or absence of 'illat). The prohibition isbāl aimed specially for people who do it because of their arrogance, not to people who do it without their arrogance
\end{abstract}

Keywords: Contextual, Understanding, Isbāl

Abstrak. Penelitian ini bertujuan untuk menganalisis perbedaaan dikalangan umat Islam
dalam memahami hadis-hadis isbāl yang difokuskan pada dua pertanyaan. Pertama;
apakah larangan isbāl yang terdapat dalam berbagai hadis murni merupakan normatifitas
agama, atau terdapat alasan-alasan sosiologis untuk kepentingan tertentu. Kedua;
bagaimana sebaiknya memahami hadis-hadis larangan isbāl. Kajian terhadap isu ini
menggunakan pendekatan sosiologis dan metode tematis korelatif. Hasil penelitian
menemukan bahwa hadis-hadis larangan isbāl merupakan hadis tasyriłiyyah (berdaya
hukum/ normatifitas), namun hukumnya tidak berlaku universal, tetapi bersifat
kondisional. Hal ini dikarenakan, munculnya hadis-hadis larangan isbāl tidak terlepas
dari faktor sosiologis waktu itu, yakni bentuk penolakan Nabi saw. terhadap budaya
jahiliah. Kajian korelatif hadis menemukan bahwa 'illat larangan isbāl adalah khuyyala'
(kesombongan). Hadis-hadis larangan isbāl sebaiknya dipahami secara kontekstual 
dengan menggunakan kaidah ushul fikih yadūrul ḥukmi ma'a al-'illah wujūdan wa'adaman (berlakunya hukum sangat terkait dengan ada atau tidaknya 'illat). Larangan isbāl tersebut ditujukan khusus kepada orang orang yang melakukannya karena kesombongan, bukan kepada orang yang melakukanya dengan tanpa kesombongan

Keyword: Kontekstual, Pemahaman, Isbāl

\section{Pendahuluan}

Pada dekade dua puluh tahun terakhir terutama setelah tumbangnya Orde Baru, di Indonesia muncul komunitas yang terkesan ekslusif karena keberadaan mereka cenderung membela diri dari "segala yang berlangsung" secara umum disekitar masyarakat mereka. Antara lain yang termasuk kelompok ini adalah komunitas yang dikenal dengan Salafi dan Jamaab Tabligh.

Belakangan ini kelompok Jamaah Tabligh sudah mulai membuka diri (inklusif), dengan bergaul dan mengikuti aktifitas masyarakat disekitar mereka. Sementara kaum Salafi baik Salafi Jihadi maupun Salafi Dakwah masih terlihat ekslusif. Menurut pengamatan penulis, keterbukaan kelompok Jamaah Tabligh dimotivasi oleh orientasi harakoh kelompok ini yang lebih mengutamakan dakwah, khurüj, dan memakmurkan masjid.

Terlepas dari perbedaan tersebut, yang jelas kedua komunitas ini berusaha menerapkan semua prilaku Nabi saw. dalam kehidupan termasuk dalam hal berpakaian, yang mereka sebut dengan istilah ittibā' al-sunnah (mengikuti sunnah Nabi), dan ihyā' as-Sunnah (menghidupkan sunah). Pakaian yang mereka kenakan berbeda dengan cara berpakaian orang lain secara umum. Tanda-tanda pakaian mereka yang mencolok adalah para perempuan dikalangan mereka memakai niqā $b$ (cadar atau bentuk pakaian warna hitam yang melindungi seluruh tubuh/hanya kelihatan mata). Sedangkan para pemuda mereka memakai jalabiah (jubah panjang), 'imāmah (serban), lihyah (berjenggot panjang), dan ghairu isbāl, (mengenakan pantalon yang panjangnya tidak sampai mata kaki), ${ }^{1}$ bahkan diantara mereka ada yang mengenakan celana "setengah tiang". Dua hal yang disebut terakhir yakni lihyah (berjenggot panjang) dan ghairu isbāl (menghindari perbuatan isbāl merupakan ciri utama kedua kelompok ini. Pilihan atau sikap mereka dalam berpakaian dan penampilan tersebut bersumber dari hadis-hadis Nabi saw.

Secara umum umat Islam memahami hadis larangan isbāl secara tekstual. mereka mengangggap berpakaian dengan cara ghairu ishāl (menghindari perbuatan $i s b \bar{a} l$ merupakan kewajiban yang harus dilakukan oleh setiap muslim. Bahkan menurut pengamatan Yusuf al-Qardhawi sebagian anak-anak muda 
kelompok tekstualis tersebut bersikap sinis terhadap orang yang memanjangkan pentalon atau celana melewati mata kaki, dengan menganggap pelaku is $b \bar{a} l$ sebagai orang yang tidak bagus agamanya karena tidak mengikuti sunnah. ${ }^{2}$ Disamping itu, sebagian umat Islam yang lain memahami hadis-hadis larangan isbäl tersebut secara kontekstual. Bagi kelompok ini berprilaku isbāl dalam berpakaian tidaklah dilarang.

Penelusuran awal penulis menemukan; Pertama, dari segi sanad dan matan hadis-hadis isbāl banyak memiliki variasi. Dalam beberapa riwayat ditemukan hadis yang melarang $i s b \bar{a} l$, namun pada hadis lain Nabi saw. membolehkan isbāl. Kedua, para ulama berbeda dalam memahami hadis $i s b \bar{a} l$, namun mayoritas ulama baik klasik maupun kontemporer, antara lain Muhammad Yusuf al-Qardhawi dari Mesir, Ahmad Hassan, dan Muhammad Syuhudi Ismail dari Indonesia memahami dan menyelesaikan kontroversi hadis-hadis $i s b \bar{a} l$ tersebut sehingga menghasilkan kesimpulan bahwa hadis-hadis tersebut harus dipahami secara kontekstual (ma'nawiyah). Dalam pandangan kelompok kontekstualis, isbäl dalam berpakaian tidaklah dilarang secara mutlak.

Fenomena perbedaan dalam menyikapi dan memahami hadis isbäl sebagaimana tersebut di atas menarik untuk diteliti lebih lanjut. Bagaimana sebenarnya duduk persoalan dan bagaimana sebaiknya memahami hadis-hadis larangan $i s b \bar{a} l$ tersebut.

Kajian terhadap hadis-hadis isbäl antara lain telah dilakukan oleh:1) Muhammad Nasir dalam artikel jurnal yang berjudul, "Kontroversi Hadis-Hadis Tentang Isbal (Telaah Kritis Sanad dan Matan Hadis serta Metode Penyelesainnya)". ${ }^{3}$ Tulisan tersebut lebih difokuskan pada kajian takbrij al-hadiš, sanad, matan dan penyelesaian kontroversi hadis-hadis $i s b \bar{a} l$ dengan pendekatan ushul fikih atau ilmu mukbtalif al-hadisis. 2) Sulidar menulis artikel berjudul, "Analisis Hadis-Hadis Tentang Isbal". ${ }^{4}$ Tulisan tersebut mencoba memahami hadis isbāl dengan metode naqd al- matan (kritik matan hadis) dan pendekatan korelatif dengan riwayatriwayat lain. 3. Fathul Hidayat dan Toni Markos menulis artikel berjudul, "Hadis-

${ }^{2}$ Yusuf al-Qardhawiy, Metode Memahami Sunnah Dengan Benar, judul asli Kaifa Nata'ammal Ma'a al-Sunnah Nabawiyah Ma'alim wa Dawäbit, penerjemah Saifullah Kamalie, (Jakarta: Media Dakwah, 1994), 175-176.

${ }^{3}$ Muhammad Nasir, "Kontroversi Hadis-Hadis Tentang Isbal (Telaah Kritis Sanad dan Matan Hadis serta Metode Penyelesainnya)", Jurnal Farabi 10 No. 1(Juni 2013): 81-95.

${ }^{4}$ Sulidar, "Analisis Hadis-Hadis Tentang Isbal", Jurnal Al-Kaffah 4, No.2 Juli-Desember 2016): 96-134. 
Hadis Tentang Isbal: Studi Pemahaman dan Pengamalan di SDIT dar el-Iman Padang". Sesuai dengan judulnya tulisan tersebut lebih membahas pemahaman dan pengamalan hadis isbāl di SDIT Dar el-Iman Padang. Dengan menggunakan pendekatan living hadis, penelitian tersebut mengungkap corak pemahaman dan faktor-faktor pengamalan hadis isbāl dikalangan para guru. 4. Muhammad Rezi menulis tulisan yang berjudul, Isbâl Dalam Prespektif Variasi Hadis. ${ }^{6}$ Dalam kesimpulannya, Rezi berpendapat bahwa Variasi hadis isbāl dapat dijelaskan dengan teori mutlaq dan muqayyad dengan melahirkan kesimpulan bahwa isbâl dilarang ketika disertai dengan kesombongan dan tidak menjadi masalah jika tanpa disertai rasa sombong. 5. Bobby Zulfikar Akbar menulis artikel berjudul, "Kontekstualisasi Hadits Tentang Anjuran Memelihara Jenggot Dan Larangan Isbal Pada Zaman Kekinian". ${ }^{7}$ Sama dengan tulisan sebelumnya kajian tersebut lebih terfokus pada pemahaman dengan metode korelatif dengan riwayat-riwayat lain. 6. Miski menulis tulisan berjudul, "Fenomena Meme Hadis Celana Cingkerang di Media Sosial" 8 Penelitian tersebut murni membahas motif gerakan indentitas celana cingkrang di Media Sosial dan tidak sama sekali membahas kajian hadis baik aspek sanad, matan, maupun pemahaman.7. Armansyah menulis tulisan yang berjudul, "Polemik Isbal dan Sombong Serta Pendapat Ulama Terkait Mukhtalif Al Hadits", 9 Tulisan tersebut lebih fokus pada iventarisasi hadis-hadis $i s b \bar{a} l$ yang termasuk kategori hadis mukhtalif dan memaparkan perbedaan pendapat para ulama. Tulisan tersebut sama sekali belum melakukan analisis aspek pemahaman hadis. 8. Muhammad Yusron dan Muhammad Alfatih Suryadilaga menulis tulisan berjudul, "Fenomena Isbal dan Memanjangkan Jenggot: Analisis Sejarah Sosial Hadis Nabi Muhammad". 10 Tulisan tersebut mencoba memahami hadis is $b \bar{a} l$ dan memanjangkan jenggot dengan analisis sejarah sosial ketika Nabi saw. mengucapakan hadis tersebut. Penelitian tersebut menyimpulkan bahwa fenomena yang mengiringi hadis larangan is $b \bar{a} l$ adalah prilaku sombong yang hinggap pada individu tanpa terbatas pada satu generasi. Larangan Nabi saw. terhadap praktek isbāl tersebut

${ }^{5}$ Fathul Hidayat dan Toni Markos, "Hadis-Hadis Tentang Isbal: Studi Pemahaman dan Pengamalan di SDIT dar El-Iman Padang”, Jurnal Istinarah 1 No. 1, (Juli 2019): 54-66. 2016): 81-91.

${ }^{6}$ Muhammad Rezi, "Isbâl dalam Prespektif Variasi Hadis", Jurnal Ulunnuba 6 No.1 (Juni

${ }^{7}$ Bobby Zulfikar Akbar, "Kontekstualisasi Hadits Tentang Anjuran Memelihara Jenggot Dan Larangan Isbal Pada Zaman Kekinian", Jurnal Al-Drikera 12, No. 2, (Desember Tahun 2018): 137-163.

${ }^{8}$ Miski, "Fenomena Meme Hadis Celana Cingkrang di Media Sosial ", Jurnal Multikultural \& Multireligius 16 No. 2. (Desember 2017): 291-305.

${ }^{9}$ Armansyah, "Polemik Isbal dan Sombong Serta Pendapat Ulama Terkait Mukhtalif Al Hadits”, Sangaji: Jurnal Pemikiran Syariah dan Hukum, 3, Nomor 2, (Oktober 2019): 244-263

${ }^{10}$ Muhammad Yusron dan Muhammad Alfatih Suryadilaga, "Fenomena Isbal dan Memanjangkan Jenggot: Analisis Sejarah Sosial Hadis Nabi Muhammad", Indonesian Journal of Islamic Literature and Muslim Society , 3 No.2 (Juli- Desember 2018): 137-155. 
dikarenakan pelakunya sombong. 9. Muhammad Iqbal menulis tulisan yang berjudul, "Hadis-hadis Mukbtalif tentang Pakaian dan Perbiasan". ${ }^{11}$ Tulisan tersebut mencoba menyelesaikan hadis-hadis mubktainf terkait tema tersebut, namun hanya sebatas tema memakai sendal, sutera dan mengusap khuff, sedikitpun tidak membahas hadis-hadis isbäl. 10. Abd Halim menulis tulisan yang berjudul, "Dialektika Hadis Nabi dengan Budaya Lokal Arab". ${ }^{12}$ Tulisan tersebut membahas sikap atau respon al-Qu'ran dan hadis Nabi saw. terhadap budaya Arab. Menurutnya terdapat tiga bentuk respons atau dialektika hadis Nabi saw. dengan budaya Arab; pertama, tahmīl (adoptive complement) atau sikap yang mengapresiasi. Kedua, taghyīr (Adoptive-reconstructive) yakni menerima tetapi memodifikasinya. Ketiga, tabrim (Destructive) yakni sikap penolakan. Dalam pembahasannya Abd Halim memberikaan contoh-contoh dari ketiga hal tersebut antara lain tentang budaya berpakaian. Namun, pembahasan tersebut sama sekali belum membahas atau menyinggung tentang hadis-hadis $i s b \bar{a} l$.

Sejauh pembacaan dan penelaahan penulis terhadap literatur-literatur yang disebutkan di atas, belum ditemukan tulisan yang mengkaji atau memahami hadis isbäl secara totalitas (tidak bersamaan dengan pembahasan hadis jenggot), komprehensif yang tidak hanya membahas dari persefektif sanad dan matan, tetapi juga memahami hadis tersebut dengan pendekatan sosiologis yang memperhatikan budaya atau tradisi Arab baik pada pra Islam maupun awal Islam. Karena itu analisis yang penulis lakukan dalam penelitian ini memiliki kebaharuan dan perbedaan dengan kajian terdahulu.

Permasalahan atau kegelisahan akademik penelitian ini adalah; Pertama, apakah larangan is $b \bar{a} l$ murni normatifitas agama, ataukah "jangan-jangan" merupakan imbas dari konstruksi sosial budaya pada saat itu?, atau ada alasanalasan sosiologis sehingga is $b \bar{a} l$ dilarang oleh Nabi saw. Kedua, bagaimana sebaiknya memahami hadis-hadis larangan isbāl.

Asumsi penulis mengatakan bahwa larangan dan kebolehan isbāl yang disampaikan oleh Nabi tersebut sangat terkait dengan tradisi atau budaya masyarakat waktu itu. Asumsi ini berawal dari bervariasinya teks hadis-hadis $i s b \bar{a} l$ dan terdapatnya perbedaan pendapat para ulama dalam memahaminya. Jika asumsi ini benar, maka implikasinya adalah hadis-hadis $i s b \bar{a} l$ perlu dipahami secara kontekstual, karena antara kandungan hadis yang satu dengan hadis yang

${ }^{11}$ Muhammad Iqbal, "Hadis-hadis Mukhtalif tentang Pakaian dan Perhiasan", Jurnal Mudarrisuna 7, Nomor: 1, (Januari-Juni 2017): 66-76

${ }^{12}$ Abd Halim, "Dialektika Hadis Nabi dengan Budaya Lokal Arab", Dinika, 4, Nomor: 1, (Januari - April 2019): 65-82. 
lain saling menjelaskan. Memahami hadis secara tekstual apalagi mengharuskan orang lain mengikuti pemahaman tekstual tersebut merupakan sikap yang keliru dan gegabah, karena hanya melihat hadis secara parsial dan belum komprhensif.

Penulis berusaha menjawab pertanyaan-pertanyaan di atas dengan mengkaji hadis larangan isbäl dengan pendekatan sosiologis ${ }^{13}$ dan metode korelatif ${ }^{14}$, dengan terlebih dahulu memaparkan pendapat para ulama. Data-data yang diperoleh dianalisis isinya (content analiysis), kemudian diinterpretasikan secara deskrptif analysis. Penggunaan pendekatan dan metode tersebut diharapkan mampu mengungkap alasan-alasan sosiologis dari pelarangan isbāl sehingga dapat memberikan tawaran metode yang tepat dalam memahami hadis-hadis tersebut.

\section{Pengertian IsbāI}

Kata isbāl berasal dari kata asbala bermakna al-sitr (menutupi), al-Irsā $l$ (mengurai) al-țañ̄lah (memanjangkan), ${ }^{15}$ al-nā̧̃il artinya (menurunkan). ${ }^{16}$ Perbuatannya dinakaman $i s b \bar{a} l$, yakni memakai pakaian yang menutup mata kaki, sedangkan pelakunya disebut al-musbill.

Dari beberapa referensi yang penulis temui, terutama dari kitab Fath alBāriy dan Șahīh Muslim bi Syarh al-Nawāwiy, maka definisi isbäl secara istilah (kontek kajian hadis) adalah:" Kaum laki-laki yang memakai pakaian (celana, kain, jubah, sarung) dengan memanjangkan ujung pakaiannya sampai menutup mata kaki atau lebih"

\section{Inventarisasi Hadis}

Penulis melacak hadis-hadis yang berkaitan dengan isbāl dari beberapa kata, pertama dari kata الاسبال, kedua dari kata المسبل, yang ketiga dari kata جر

${ }^{13}$ Pendekatan sosiologis sangat penting dilakukan dalam studi keislaman, karena pendekatan ini memahami agama dengan memperhatikan gambaran tentang keadaan masyarakat lengkap dengan struktur, lapisan serta berbagai gejala sosial lainnya yang saling berkaitan. Melalui pendekatan ini agama akan dapat dipahami dengan mudah karena agama sendiri diturunkan untuk kepentingan sosial. Lihat: M. Arif Khoiruddin, "Pendekatan Sosiologi dalam Studi Islam", Tribakti: Jurnal Pemikiran Keislaman 25 Nomor 2 (September 2014): 394, 407.

${ }^{14}$ Yang dimaksud dengan metode korelatif dalam penelitian ini adalah: 1) mengkorelasi hadis-hadis larangan isbäl dengan hadis-hadis lain yang terkait (Jam'u al-Aḥ̂adis al-Wäridah fi mau dü ' al-wäbid kemudian mengambil pemahaman secara utuh, sebagaimana yang telah dicetus oleh Yusuf al-Qardhawi. Lebih lanjut Lihat: Yūsuf al-Qardhawī, Metode Memahami Sunnah Dengan Benar, judul asli Kaifa Nata'ammal Ma'a al-Sunnah Nabawiyah Ma'alim wa Dawäbiț, 106. 2) mengkorelasi hadis-hadis tentang isbäl dengan riwayat-riwayat lain seperti syair, informasi tradisi atau budaya Arab, dan lain-lain.

${ }^{15}$ Louweis Ma'luf, al-Munjid fi al-Lughah wa al'Alām, (Bairūt: Dār al-Masyriq, 1997), 320.

${ }^{16}$ Ali Muthahar, Kamus Muthahar, (Jakarta: Hikmah, 2005), 59. 
لثوبه dan yang keempat dari kata الايز ار. Hasil penelusuran tersebut adalah sebagai berikut:

\section{Riwayat Muslim}

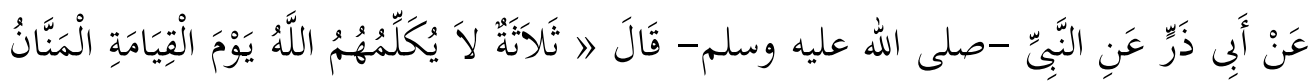

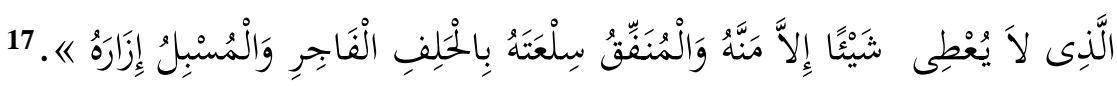

"Dari Abu Żar dari Nabi saw. berkata: "Ada tiga orangyang mana Allab tidak mengajak mereka bicara pada hari kiamat: Orang yang suka memberi, dia memberi melainkan dengan menyebut-nyebutkannya (karena riya'), orang yang membuat laku barang dagangannya dengan sumpah palsu, serta orangyang melakukan isbāl (memanjangkan) pakaian".

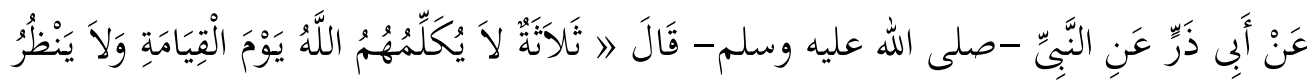

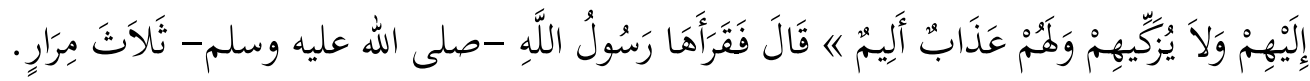

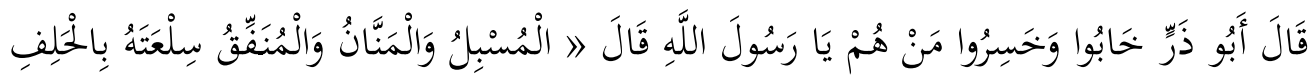

18 . الْكاذِبْ

"Dari Abu Żar dari Nabi saw. berkata: "Tiga golongan manusia yang Allab tidak akan mengajak mereka bicara pada hari kiamat, tidak melihat mereka, tidak mensucikan dosanya dan mereka akan mendapatkan sikesa yang pedib." Abu Dzar berkata lagi, "Rasulullah Șhallallahu 'alaibi wasallam membacanya tiga kali. Abu Żar berkata, "Mereka gagal dan rugi, siapakah mereka wahai Rasulullah?" Beliau menjawab, "Orang yang melakukan isbāl (memanjangkean pakaian), orang yang suka memberi dengan menyebut-nyebutkannya (karena riya'), dan orang yang membuat laku barang dagangan dengan sumpah palsu".

\section{Riwayat al-Nasāi:}

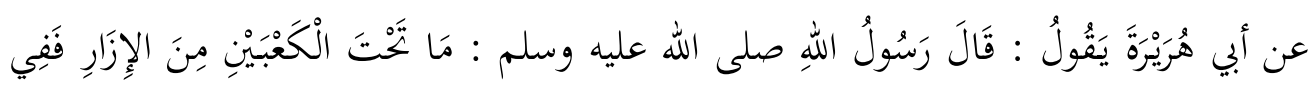
19 اللَّارِ

${ }^{17}$ Abi al-Husain Muslim ibn al-Hajjaj Ibn Muslim Ibn al- Qusyairiy, al-Jāmi' al-Ṣabih (selanjutnya disebut Șahih Muslim), (Bairūt: Dār al-Fikr, t.tt.), vol. 1, 71.

${ }^{18}$ Ibid.

${ }^{19} \mathrm{Abd}$ al-Raḥmān Aḥmad Ibn Syu’aib al-Nasāi, Sunan al-Nasäi, (Bairūt; Dār al-Fikr, Daār al-Iḥ̂ā’ al-Turās̀ al-'Arabīy, t.t.), 886. 
"Abu Hurairah berkata, "Rasulullah saw. berkata: "Kain sarung yang ada di bawah mata kaki tempatnya adalah di neraka".

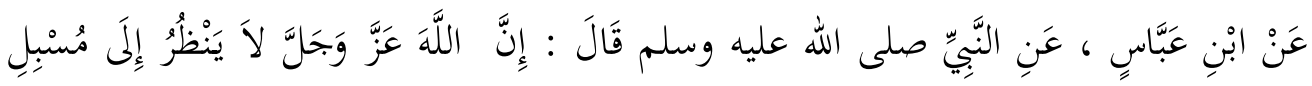 الإزَّار 20}

"Dari Ibnu Abbas dari Nabi saw.ia berkata: "Sesunggubnya Allab 'azza wajalla tidak akan melihat orang yang memanjangkean kain sarungnya (di bawah mata kaki.)"

\section{Riwayat al-Bukhāı̄i}

عن أبي هريرة رضي الله عنه عن النبي صلى الله عليه و سلم قال ما اسفل من الكعبين من الإزار ففي النار 21

"(al-Bukhā̄in meriwayatkan)........ dari Abu Hurairah, Rasulullah saw. berkata: pakaian yang lebih rendah dari mata kakinya (pelakunya) akan dimasukean kedalam neraka".

عَنِ ابْنِ عُمَرَ رَضِيَ اللَّهُ عَنْهُهما أَنَّ رَسُولَ اللهِهِ صلى الله عليه وسلم قَالَ : لاَ يَنْظُرُ اللَّهُ إلَّى مَنْ

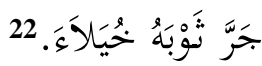

"Dari Ibnu Umar r.a. bahwa Rasulullah saw.berkata: "Allah tidak akan melihat orang yang menjulurkan pakaiannya dengan sombong."

عَنْ عَبْدِ اللَهِ بْنِ عُمَرَ رَضِيَ اللَّهُ عَنْهُمَا، قَالَ : قَالَ رَسُولُ اللهِهِ صلى الله عليه وسلم : مَنْ جرََّ

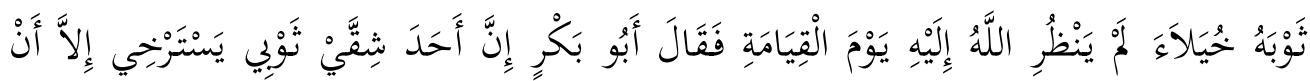

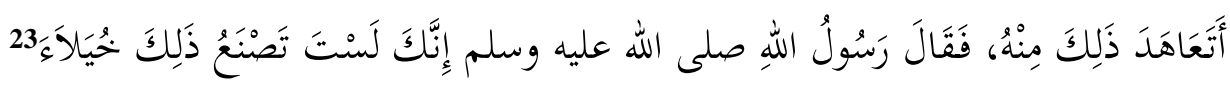

'Dari Abdullah bin 'Umar ra. dari Nabi saw.berkata: "Siapa yang menjulurkan pakaiannya karena kesombongan maka Allah tidak akan melihat kepadanya pada hari kiamat". Kemudian Abu Bakar berkata; "Sesunggubnya sebelah dari pakaianku terjulur kecuali bila aku memeganginya (mengangkatnya) ". Maka Rasulullab Șallallabu 'alaibi wasallam berkata: "Sesunggubnya kamu melakukan itu bukan bermaksud sombong".

${ }^{20}$ Ibid.

21 Abū Abdillah Muḥammad Ibn Ismaīl Ibn al-Bukhārī (selanjutnya disebut al-Bukhārī), Șahih al-Bukhārì, (Bairūt: Dār al-Fikr, 1981), vol.4, 34.

${ }^{22}$ Ibid.

${ }^{23}$ Ibid. 


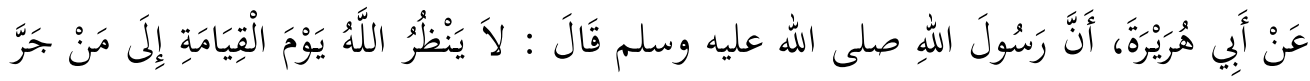 \\ 24.}

"Dari Abu Hurairah bahwa Nabi saw. berkata: "Pada hari kiamat kelak, Allah tidak akan melihat orang yang menjulurkan kain sarungnya karena sombong"

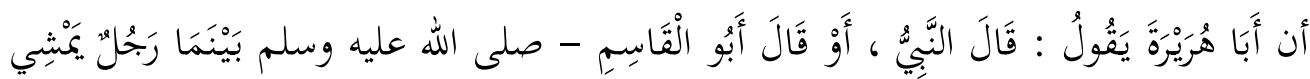

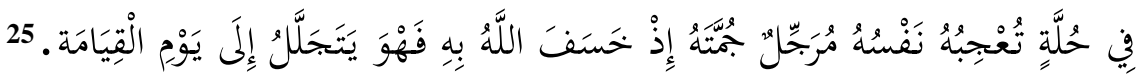

"Abu Hurairah berkata; Nabi saw. berkata atau Abu Qasim berkata: "Ketika seorang lelaki berjalan dengan menggunakan jubah yang ia kenakan, dan berjalan dengan rasa ta'ajub, lalu ia ditelan (oleb bumi), dan ia akan tetap berguncang-guncang (di dalam perut bumi) bingga datang hari kiamat."

\section{Asbāb al-Wurūd al-Hadiś}

Hadis-hadis di atas mempunyai sebab secara khusus. Ibnu Hamzah alHusaini al-Dimasyqiy (pakar asbāb al-wurüd), mengatakan bahwa asbāb al-wurüd hadis larangan isbäl terdapat dua versi. Pertama, Abu Hurairah melihat seorang pemimpin (pejabat) dari Bahrain, memakai pakaian yang menjulur sampai menyapu tanah, orang tersebut mengatakan pemimpin (pejabat kalian) telah datang. Maka hal ini diceritakan kepada Rasulullah, maka beliau bersabda : 26

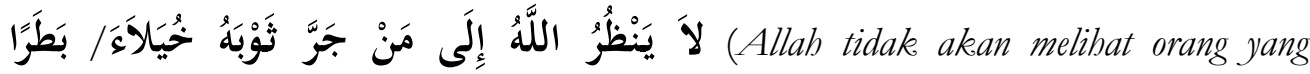
menjulurkan kain sarungnya karena sombong).

Versi yang kedua menyebutkan, bahwa Ibnu Umar berjalan dengan mengunakan pakaian yang menjulur sampai kepada tanah, dalam perjalanan tersebut dia berpapasan dengan Rasulullah saw., maka Rasulullah saw. mengatakan wahai Abdullah bin Umar angkat sedikit kainmu. Maka Ibnu Umar menganggkatnya, kemudian Rasulullah saw. kembali mengatakan angkat sedikit lagi, kemudian Ibn Umar mengangkatnya, begitu terus sehingga berulang-ulang. ${ }^{27}$

${ }^{24}$ Ibid.

${ }^{25}$ Ibid., 35.

${ }^{26} \mathrm{Ibn}$ Hamzah al-Husainī al-Hanafi al-Dimasyqī, Al-Bayān Wa al-Ta'rîf Fì Asbāb al-Wurūd al-Hadìs al-Syarif, (Bairūt: Dār al-Śaqofah al-Islāmiyyah, t.t.), Vol. 1,. 418-419.

${ }^{27}$ Ibid. 
300 | AL QUDS : Jurnal Studi Alquran dan Hadis vol. 5, no 1, 2021

\section{Fahm al- Hadis}

Menurut Ibnu hajar al-Asqlani, isbāl yang dilarang dalam hadis di atas adalah isbāl yang dilakukan karena sombong dan merupakan dosa besar. Sedangkan isbāl yang tidak dilakukan karena sombong tidak dilarang. Sebagaimana ungkapannya:

وفي هذه الأحاديث أن إسبال الإزار للخيلاء كبيرة، وأما الإسبال لغير الخيالاء فظاهر الأحاديث تحريمه أيضا، لكن استدل بالتقييد في هذه الأحاديث بالخيلاء على أن الإطلاق في الزجر الوارد

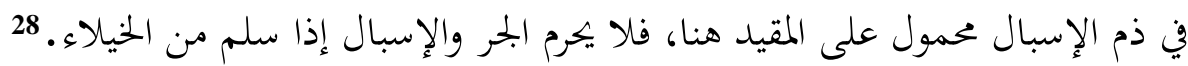

"Dalam hadis-hadis ini (di atas) disebutkan bahwa memanjangkan kain (isbäl) karena angkuh adalah al-kabirah. Adapun melakukan isbäl dengan tidak sombong, sebenarnya zohir hadis menyebutkan juga diharamkan, akan tetapi karena yang dilarang oleb Nabi karena sombong, maka tidak haram atau tidak terlarang orang melakukan isbäl apabila selamat dari kesombongan."

Imam al-Nawawi ketika mensyarah hadis-hadis isbal di atas menyatakan :

$$
\begin{aligned}
& \text { وأما قوله صلى الله عليه و سلم المسبل ازاره فمعناه المرخى له الجار طرفه خيلاء كما جاء مفسرا } \\
& \text { في الحديث الآخر لا ينظر الله إلى من يجر ثوبه خيلاء والخياء الكبر وهذا التقييد بالجر خيلاء } \\
& \text { يخصص عموم المسبل ازاره ويدل على أن المراد بالوعيد من جره خيلاء وقد رخص النىى صلى } \\
& \text { الله عليه و سلم في ذلك لابى بكر الصديق رضى الله عنه وقال لست منهم. } 29
\end{aligned}
$$

"Adapun makna (isbāl yang dilarang dalam) hadis Nabi tersebut adalab orang-orangyang memanjangkan kainnya (menutup mata kaki) sehingga ujung kainnya menyeret (menyapu tanah/laintai) karena sombong. (pemahaman ini diketahui) dari penafsiran hadis lain, pertama hadis La yanzhurullah ila man jarra tsaubahu khuyyyala', yang kedua hadis yang nenyebutkean bahwa nabi memberi keringanan (isbäl) kepada Abu bakar, karena Abu Bakar melakukannya bukan karena sombong. Jadi dapat dipahami ancaman dalam hadis ini adalah isbäl yang dilakukan karena sombong.

Dari ungkapan di atas dapat diketahui bahwa dalam pandangan imam Nawawi isbāl yang dilarang atau diancam dalam hadis di atas adalah isbāl yang disertai dengan sombong (khuyyalä) dan keangkuhan (batran). Menurutnya hal ini

${ }^{28}$ Al-Ḥafiz Aḥmad Ibn 'Ali Ibn Hajar al-'Asyqalānī, Fatḥ al-Bārì, ( Bairūt: Dār al-Kutub al-'Ilmiyyah, t.t.), vol. 11, 224.

${ }^{29}$ Abū Zakariya Muḥyuddin al-Nawāwī, Șabih Muslim Bi Syarḥ al-Nawāwñ (Bairūt: Dār alFikr, t.th), Vol. 2, 116. 
dapat diketahui dari hadis yang yang menjelaskan dispensasi Nabi terhadap Abu Bakar dengan ucapan lasta minhum: engkau tidak termasuk bagian dari mereka, karena Abu Bakar memanjangkan pakaiannya bukan karena sombong.

Sedangkan Al-Syaukānī Didalam kitab Nail al-Auțor al-Syaukānī lebih jelas lagi menyebutkan bahwa isbäl tanpa sombong tidak dilarang, sebagaimana ungkapannya:

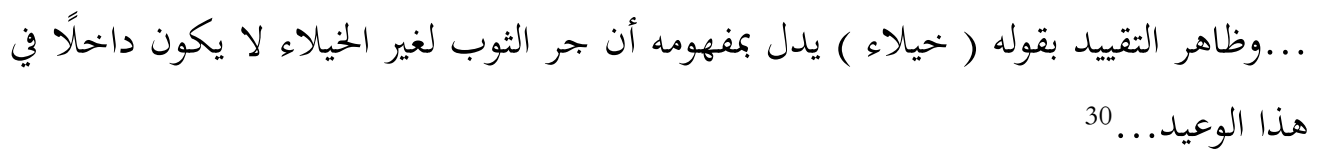

"Zabir (hadis isbāl ini) dalam memahaminya sangat terkait dengan kata kbuyyala'(angkuh). Hal ini memberikan pemahaman bahwa orang yang memanjangkan pakaian tetapi tidak angkuh, tidak termasuk dalam ancaman hadis ini".

Al-Shan'ani dalam kitab Subul al-Saläm, berpendapat bahwa hadis-hadis larangan isbäl sangat terkait dengan illat-nya yakni kata khuyyala'(sombong). Maka isbäl dengan tanpa kesombongan tidak termasuk dalam ancaman hadis ini. Sebagaimana ungkapannya:

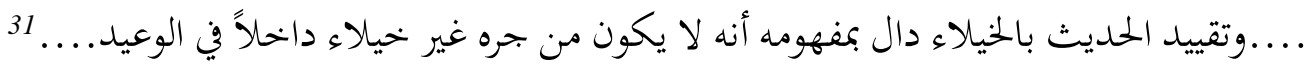

"Hadis ini berkaiatan dengan kalimat al-khuyyala' (illlatnya karena sombong). Hal ini memberi pengertian bahwa orang yang menjulurkan pakaianny a tanpa angkub tidak. termasuk. dalam ancaman hadis ini.

Al-Suyuthi sebagaimana dikutip oleh Abdul Somad juga memahami bahwa kalimat al-musbil iəăa rabu adalah orang yang memanjangkan kainnya sampai mata kaki karena sombong. Hadis ini menurut al-Suyuthi harus dipahami dari hadis lain yakni hadis yang menyebukan bahwa Nabi memberikan dispensasi kepada Abu Bakar melakukan isbäl, sebab Abu Bakar melakukannya tidak karena angkuh. ${ }^{32}$

Yusuf al-Qardawi seorang pakar hadis kontemporer berpendapat bahwa untuk memahami hadis dengan tepat dan terhindar dari kesalahan diperlukan metode korelatif (Jam'u al-Ahāäïs al-Wäridah fi mauḍū' al-wähid), yakni mengumpulkan hadis-hadis dalam satu tema kemudian mengaitkannya dengan

${ }^{30}$ Muḥammad ibn 'Ali Ibn Muḥammad al-Syaukānī, Nail al-Auțor Min Abadïs Sayyid alAkbbār Syarḥ Muntaqā al-Akbbār, (Bairūt : Dār al-Jaiil, 1983), vol. 2, 112. $1468 \mathrm{H}), 154$.

${ }^{31}$ Muḥammad Ibn Ismaīl al-'Amir al-Ṣan'anī, Subul al-Salām (Bairūt: Dār Ibn al-Jauzī,

32Abdul Somad, 37 Masalah Populer, (Pekan Baru: Tafaqquh Media, 2017), 166. 
hadis-hadis lain. Metode ini sangat penting karena makna suatu hadis kadang kala penjelasannya terdapat pada hadis-hadis lain. Melihat hadis secara parsial ( hanya melihat satu zhahir hadis tanpa melihat hadis-hadis dan nas lain yang terkait) seringkali menjerumuskan seseorang kedalam kesalahan dan menjauhkannya dari kebenaran dan tujuan yang terkandung dalam hadis. ${ }^{33}$ Salah satu hadis yang harus dipahamami dengan kontekstual korelatif adalah hadis-hadis tentang isbäl. Menurut Yusuf al-Qardhawiy, berdasarkan hadis-hadis yang menyebutkan dispensasi Nabi saw. kepada Abu Bakar, maka hadis-hadis ancaman dan larangan isbäl dipahami mempunyai 'ilat kesombongan. Dengan kata lain bahwa yang dilarang oleh Rasulullah adalah memanjangkan kain tersebut karena kesombongan. Apabila tidak sombong maka hal tersebut tidak termasuk ke dalam ancaman hadis yang pertama tadi. ${ }^{34}$

Menurut Kholil Abu Fatih, hadis-hadis larangan isbäl harus dikaitkan dengan hadis yang menyebutkan dispensasi Nabi terhadap isbäl Abu Bakar, karena Abu Bakar melakukannya bukan berdasarkan kesombongan. Maka untuk memahami hadis-hadis tentang isbäl di atas harus digunakan al-jam'u wa al-taufiq pemaduan dan penyatuan sehingga pemahaman yang dihasilkan tepat dan komprehensif. Menurutnya apabila isbäl dilakukan dengan tujuan berbangga dan menyombongkan diri (al-fakhr) maka hukumnya haram, dosa besar dan hal itu merupakan maksiat badan. Sedangkan jika melakukan isbäl tidak dengan tujuan sombong maka hukumnya makruh. ${ }^{35}$

\section{Analisis Sosiologis}

Dari segi kajian otentisitas, hadis tentang isbäl berkualitas sahih dan termasuk hadis tasyri'yyyah (berdaya hukum), menjadi otoritas yang harus diikuti. Karena perintah Nabi saw. tersebut dalam kapasitasnya sebagai Rasulullah dan pembawa risalah. Hadis tersebut merupakan nabi atau larangan Rasulullah saw. terhadap umatnya melakukan isbäl .

Akan tetapi dari segi kajian interpretasi (fahm al-ḥadìs), para ulama baik klasik maupun kontemporer memahami hadis isbäl dengan metode kontekstual, seperti yang dilakukan oleh al-Qardhawi yang menggunakan metode koleratif, yakni mengaitkan suatu hadis dengan hadis-hadis lain yang berkaitan atau satu tema (Jam'u al-Ahạadìs al-Wāridah fi mau dü' al-wāabid).

Dari segi istinbāth hukum para ulama klasik maupun kontemporer menyatakan bahwa isbäl dengan kesombongn adalah haram dan berdosa. Sedangkan hukum isbäl dengan tanpa kesombongan, terdapat perbedaan

\footnotetext{
${ }^{33}$ Yūsuf al-Qardhawī, Metode Memahami Sunnah, 175.

${ }^{34}$ Ibid.,176-177.

${ }^{35}$ Kholil Abu Fatih, Masail Diniyyah, (Yogyakarta: Mitra Pustaka, 2012), 185-186.
} 
pendapat dikalangan para ulama, sebagian ulama me-makrub-kan (seperti imam alNawāwī), dan sebagian yang lain membolehkan atau tidak melarang (seperti Yusuf al-Qardhawi). Para ulama yang membolehkan isbäl dengan tanpa kesombongan tersebut memahami ancaman neraka dalam hadis di atas hanya tertuju kepada praktek isbäl yang dilakukan oleh pelakunya berdasarkan khuyyalä (sombong) dan bațran (angkuh).

Penulis lebih cenderung menerima pendapat yang membolehkan isbal dengan tanpa kesombongan seperti yang disampaikan Yusuf al-Qardhawi dengan pertimbangan; Pertama, metode yang digunakan adalah metode korelatif hadis. Keunggulan metode ini antara lain dapat menghasilkan pemahaman yang lebih komprehensif. Dengan metode korelatif dapat diketahui penjelasan Nabi saw. dalam sebuah hadis ada kalanya terdapat pada hadis lain, dan jawaban Nabi saw. terhadap permasalahan yang sama ada kalanya berbeda-beda tergantung dengan kondisi audien (sahabat yang bertanya).

Kedua, ditinjau dari analisis sosiologis, tradisi isbāl dengan memanjangkan jubah atau kain sampai mata kaki bahkan sampai "menyapu" tanah merupakan tradisi atau budaya kesombongan raja-raja Romawi dan Persia masa silam. Untuk menunjukkan keangkuhan dan kesombongan mereka, maka para penguasa itu memanjangkan jubah yang ujungnya dibawa oleh para pengawal dan dayang-dayang. Tradisi ini masuk pula ke masyarakat Arab Jahiliah. ${ }^{36}$ Salah satu bukti bahwa tradis ini masuk ke dunia Arab Jahiliah adalah ditemukan sya'ir berikut:

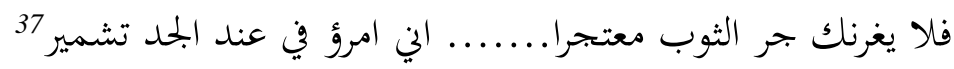

"Janganlah engkau terpesona dengan panjangnya jubah dan surban yang terurai. ".......Sesungguhnya aku juga orang yang memiliki pakaian yang panjang."

Dari syair jahiliah tersebut dapat dipahami bahwa tradisi isbäl adalah tradisi atau budaya orang-orang terdahulu sebagai lambang kesombongan. Budaya kesombongan dan keangkuhan inilah yang ingin dibantah dan ditolak oleh Rasulullah saw.

Larangan yang terdapat dalam hadis-hadis Nabi saw. pada umumnya merupakan respons Nabi saw. terhadap budaya jahiliah. ${ }^{38}$ Misalnya hadis

${ }^{36}$ Abdul Somad, 37 Masalah Populer, 168.

${ }^{37} \mathrm{Ibid}$.

${ }^{38}$ Terdapat tiga bentuk respons atau dialektika hadis Nabi saw. dengan budaya Arab; pertama, tahmil (adoptive complement) atau sikap yang mengapresiasi dan membiarkan berlakunya 
larangan meratapi mayat, hadis melarang mengambil daging dari binatang yang masih hidup, hadis tentang akikah. Jika dicermati penerapan syariat akikah yang ditetapkan oleh Nabi saw. melalui hadisnya, adalah untuk menolak (menghapus) budaya Arab jahiliah ketika menerima kelahiran anak laki-laki dengan kebanggaan dan keangkuhan, tetapi bersedih jika mendapat anak perempuan. Sebagaimana terekam dalam QS. al-Nahl:58:

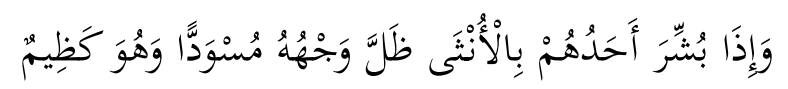

"Dan apabila seseorang dari mereka diberi berita dengan (kelahiran) anak perempuan, hitamlah (merah padamlah) mukanya, dan dia sangat marah."

Abdul Mustaqim ketika mengomentari ayat di atas menyebutkan bahwa situasi sosial masyarakat Arab waktu itu sangat tidak menyukai kehadiran bayi perempuan, kehadiran bayi perempuan dianggap malapetaka sebab tidak bisa diajak perang dan seolah-olah hanya menghabiskan makanan saja. Untuk itu Nabi mensyariatkan akikah dengan perintah menyembelih kambing ketika menerima kelahiran anak, sebagi wujud syukur kepada Allah. Hal ini menurut Abdul Mustaqim merupakan bentuk penghargaan dan pembebasan luar biasa bagi kaum perempuan pada waktu itu. ${ }^{39}$

Penulis memahami larangan Nabi saw. terhadap isbäl merupakan bentuk penolakan Nabi saw. terhadap budaya jahiliah. ${ }^{40}$ Islam tidak menentukan (mewajibkan) bentuk pakaian tertentu, umat Islam dapat menggunakan pakaian apa pun asal tidak berleih-lebihan dan angkuh. ${ }^{41}$ Prinsip dan tujuan utama dari berpakaian adalah menutup aurat, sebagaimana tergambar dalam firman Allah QS. al-'Araf:26

sebuah tradisi. Contohnya adalah sistem perdagangan. Kedua, taghyir (Adoptive-reconstructive) yakni menerima tradisi Arab tetapi memodifikasinya dengan sedemikian rupa seperti tradisi akikah. Ketiga, tabrim (Destructive) yakni sikap penolakan keberlakuan sebuah tradisi masyarakat Arab jahiliyah yang dipandang negatif dan banyak mudaratnya. Contohnya adalah budaya minum khamar, judi, riba dan mengubur bayi perempuan yang masih hidup. Lihat ; Abd Halim, "Dialektika Hadis Nabi", 68-71.

${ }^{39}$ Abdul Mustaqim, Ilmu Ma'ani al-Hadits (Yogyakarta: Idea Press, 2016), 117-119.

${ }^{40}$ Mengacu kepada teori Abd Halim, penulis berpendapat bahwa larangan isbäl termasuk pada kategori tahrim (Destructive) yakni sikap penolakan keberlakuan sebuah tradisi masyarakat Arab jahiliyah yang dipandang negatif dan banyak mudaratnya. Namun, yang di tolak oleh Nabi adalah kesombongan (tradisi sombong bagi pelaku isbäl), bukan terletak pada cara, bentuk atau jenis pakaian yang digunakan. Tesis ini antara lain didasarkan pada adanya dispensasi (kebolehan isbäl) yang diberikan Nabi saw. kepada Abu Bakar.

${ }^{41}$ Muhammad Al-Ghazali, al-Sunnah al-Nabawiyah Baina Abl Fiqh wa Abl- al-Hadïs, (Bairūt: Dār al-Syurq, 1989), 86. 


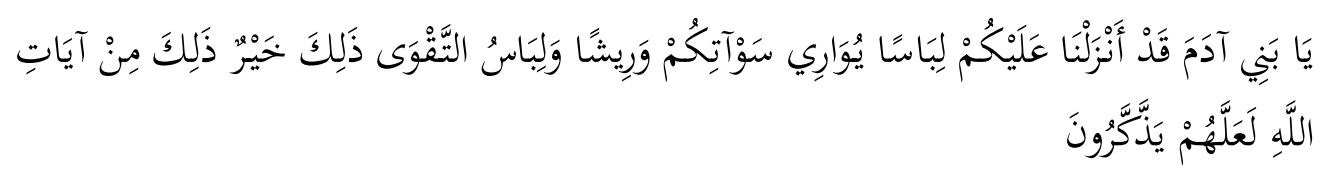

"Hai anak Adam, sesungguhnya Kami telah menurunkan kepadamu pakaian untuk menutup auratmu dan pakaian indah untuk perhiasan. Dan pakaian takwa itulah yang paling baik. Yang demikian itu adalah sebahagian dari tanda-tanda kekuasaan Allah, mudah-mudahan mereka selalu ingat."

Quraish Shihab ketika menafsirkan ayat tersebut mengatakan bahwa tujuan utama berpakaian adalah menutup aurat. Islam tidak datang menentukan bentuk (pakaian) tertentu, karena itu seluruh kelompok manusia, boleh menetapkan model (pakaian) yang cocok dengan keinginannya. Akan tetapi dalam berpakaian hendaklah tergambar indentitas. ${ }^{42}$ Pendapat Quraish Shihab di atas sejalan dengan informasi yang menyatakan bahwa Nabi saw. mengenakan pakaian yang sesuai dengan tradisi dan situasi masyarakatnya pada saat itu. Nabi saw. tidak mengenakan pakaian yang berbeda dengan manusia pada umumnya, sehingga tidak ada perbedaan antara pakaian Nabi dengan yang lainnya. ${ }^{43}$ Walaupun Informasi di atas menggambarkan aḥäl Nabi saw. namun isyarat yang dapat diambil adalah perlunya berpakaian menyesuaikan dengan tradisi masyarakat setempat. Untuk konteks Indonesia, Identitas budaya Indonesia tidak mengenal pakaian yang menjulur panjang sampai "menyapu" tanah, tetapi juga asing dengan pakaian yang melewati lutut dan tidak sampai mata kaki ("setengah tiang").

Dari paparan di atas, penulis akhirnya menyimpulkan bahwa mengenakan pakaian (celana, kain, sarung dan sejenisnya) sampai menutup mata kaki pada asalnya tidaklah dilarang, larangan dan ancaman neraka dalam hadishadis isbäl di atas ditujukan kepada orang yang melakukannya karena kesombongan. Dalam kontek ini kesombonganlah yang dapat mengantarkan seseorang kepada neraka, bukan terletak pada pakaian yang dikenakan.

\section{Kesimpulan}

Ditinjau dari kajian sosiologis, larangan isbāl merupakan bentuk penolakan Nabi saw. terhadap budaya jahiliah yang biasa memakai pakaian melewati mata kaki sebagai lambang kesombongan. Kajian korelatif hadis

\footnotetext{
${ }^{42}$ Muhammad Quraish Shihab, Wawasan al-Qur'an: Tafsir Tematik atas Pelbagai Persoalan Umat, (Bandung: Mizan, 2007), 227.

${ }^{43}$ Lihat: Muchlishon, "Cara Nabi Muhammad Berpakaian", diakses tanggal 25 Maret 2021. https://islam.nu.or.id/post/read/123512/cara-nabi-muhammad-berpakaian.
} 
menemukan bahwa illat larangan tersebut adalah sifat sombong (khuyyalāa). Hadis-hadis larangan isbäl merupakan hadis tasyri'iyyah (normatifitas) yang hukumnya tidak berlaku universal, tetapi bersifat kondisional. Karena itu hadishadis larangan isbäl perlu dipahami secara kontekstual dengan menggunakan kaidah ushul fikih: yadürul hukmi ma'a al-íllah wujüdan wa'adaman (berlakunya hukum sangat terkait dengan ada atau tidaknya 'illat). Larangan isbäl tersebut ditujukan khusus kepada orang-orang yang melakukannya karena kesombongan, bukan kepada orang yang melakukanya dengan tanpa kesombongan.

Bagi para akademisi, khususnya kalangan Studi Alquran dan Hadis (mahasiswa Ilmu Alquran dan Tafsir, Ilmu Hadis) penelitian ini dapat dijadikan motivasi awal tentang pentingnya pemahaman hadis dengan pendekatan sosiologis. Namun untuk lebih memperkaya pemikiran pemahaman hadis, penelitian ini merekomendasikan perlunya menggunakan pendekatan ilmu-ilmu sosial humaniora antara lain; antropologis psikologis, sosio historis dalam memahami hadis-hadis Nabi saw.. Karena dengan pendekatan tersebut ajaran yang terkandung dalam hadis akan lebih mudah dipahami dan menghasilkan pemahaman yang komprehensif.

\section{Bibliografi}

Abu Fatih, Kholil, Masail Diniyyah, Yogyakarta: Mitra Pustaka, 2012

Akbar, Bobby Zulfikar, "Kontekstualisasi Hadits Tentang Anjuran Memelihara Jenggot Dan Larangan Isbal Pada Zaman Kekinian”, Jurnal Al-D ə̌ikra 12, No. 2, (Desember Tahun 2018): 137-163.

Armansyah, "Polemik Isbal Dan Sombong Serta Pendapat Ulama Terkait Mukhtalif Al Hadits", Sangaji: Jurnal Pemikiran Syariah dan Hukum, 3, Nomor 2, (Oktober 2019): 244-263.

Al-'Asyqalāniy, Al-Hafizh Ahmad Ibn 'Ali Ibn Hajar, Fatḥ al-Bāriy, Bairūt: Dār al-Kutub al-'Ilmiyyah, t.t.

Al-Bukhārī, Abū Abdillah Muhammad Ibn Ismail, Al-jāmi' al-Șahị̣ (Șahịh alBukhārì), Bairūt: Dār al-Fikr, 1981.

Al-Dimasyqīi, Ibn Hamzah al-Husainiy al-Hanafi, Al-Bayān Wa al-Ta'rīf F̄̄ Asbāb Wurūd al-Hadīs al-Syañ̄f, Bairūt: Dār al-Śaqofah al-Islāmiyyah, t.t.

Al-Ghazali, Muhammad, al-Sunnah al-Nabawiyah Baina Abl Fiqh wa Abl-al-Had̄iś, Bairūt: Dār al-Syurq, 1989.

Halim, Abd, "Dialektika Hadis Nabi dengan Budaya Lokal Arab", Dinika, 4, Nomor: 1, (Januari - April 2019): 68-71.

Hasan, Noorhaidi, Laskar Jihad, Jakarta: LP3ES, 2008. 
Hidayat, Fathul dan Markos, Toni, "Hadis-Hadis Tentang Isbal: Studi Pemahaman dan Pengamalan di SDIT dar El-Iman Padang", Jurnal Istinarah 1 No. 1, (Juli 2019): 54-66.

Iqbal, Muhammad , "Hadis-hadis Mukhtalif tentang Pakaian dan Perhiasan", Jurnal Mudarrisuna 7, Nomor: 1, (Januari-Juni 2017): 66-76

Khoiruddin, M. Arif, "Pendekatan Sosiologi dalam Studi Islam”, Tribakti: Jurnal Pemikiran Keislaman 25 Nomor 2 (September 2014): 394, 407.

Ma'luf, Louweis, al-Munj̄id fì al-Lugah wa al'Alām, Bairūt: Dār al-Masyriq, 1997.

Miski, "Fenomena Meme Hadis Celana Cingkrang di Media Sosial ", Jumal Multikultural \& Multireligius 16 No. 2. (Desember 2017): 291-305.

Muchlishon, "Cara Nabi Muhammad Berpakaian", diakses tanggal 25 Maret 2021. https://islam.nu.or.id/post/read/123512/cara-nabi-muhammadberpakaian.

Muthahar, Ali, Kamus Muthahar, Jakarta: Hikmah, 2005.

Mustaqim, Abdul, Ilmu Ma'ani al-Hadits, Yogyakarta: Idea Press, 2016.

Al-Nasai, Abd al-Rahman Ahmad Ibn Syu'aib, Sunan al-Nasāi, Bairūt; Dār al-Fikr, Dār al-Ihyā' al-Turaś al-'Arabiy, t.t.

Nasir, Muhammad, "Kontroversi Hadis-Hadis Tentang Isbal (Telaah Kritis Sanad dan Matan Hadis serta Metode Penyelesainnya)", Jurnal Farabi 10 No. 1 (Juni 2013): 81-95.

Al-Nawāwī, Muhyyiddin Abū Zakaria Yahya Ibn Syaraf, Șạ̄ih Muslim bi Syarh alNawànı̀, Bairūt: Dār al-Fikr, 1983.

al-Qardhawiy, Yusuf, Metode Memahami Sunnah Dengan Benar, judul asli Kaifa Nata'ammal Ma'a al-Sunnah Nabawiyah Ma'alim wa Dawäbit, Jakarta: Media Dakwah, 1994.

Al-Qusyairiy, Abi al-Husain Muslim ibn al-Hajjaj Ibn Muslim Ibn, Al-Jāmi' alSahih, (Sahīḥ Muslim), Bairūt: Dār al-Fikr, t.t.

Rezi, Muhammad, "Isbâl dalam Prespektif Variasi Hadis", Jurnal Ulunnuba 6 No.1 (Juni 2016): 81-91.

Al-Ṣan’an̄̄, Muhammad Ibn Ismail al-‘Amir, Subul al-Salām, Bairūt: Dār Ibn alJauzīi, 1468.

Shihab, Muhammad Quraish, Wawasan al-Qur'an: Tafsir Tematik atas Pelbagai Persoalan Umat, Bandung: Mizan, 2007. 
308 | AL QUDS : Jurnal Studi Alquran dan Hadis vol. 5, no 1, 2021

Al-Sijistanī, Abī Dāwud Sulaiman Ibn al-Asy'āb, Sunan Abì Dāwnd, Bairūt: Dār al-'Ilām, 2003.

Somad, Abdul, 37 Masalah Populer, Pekan Baru: Tafaqquh Media, 2017.

Sulidar, "Analisis Hadis-Hadis Tentang Isbal", Jurnal Al-Kaffah 4, No.2 (JuliDesember 2016): 96-134.

Al-Syaukānī, Muhammad ibn 'Ali Ibn Muhammad, Nail al-Auṭor Min Ahāàìs Sayyid al-Akbbār Syarh Muntaqo al-Akbbār, Bairūt : Dār al-Jaiil, 1983.

Yusron, Muhammad dan Suryadilaga, Muhammad Alfatih, "Fenomena Isbal dan Memanjangkan Jenggot: Analisis Sejarah Sosial Hadis Nabi Muhammad", Indonesian Journal of Islamic Literature and Muslim Society , 3 No.2 (JuliDesember 2018): 137-155. 